\title{
Article
}

\section{Mediation in the Law Curriculum}

\author{
Choong, Kartina Aisha
}

Available at http://clok.uclan.ac.uk/9809/

Choong, Kartina Aisha ORCID: 0000-0001-9407-1771 (2007) Mediation in the Law Curriculum. SSRN Electronic Journal . ISSN 1556-5068

It is advisable to refer to the publisher's version if you intend to cite from the work. http://dx.doi.org/10.2139/ssrn.1013295

For more information about UCLan's research in this area go to http://www.uclan.ac.uk/researchgroups/ and search for < name of research Group>.

For information about Research generally at UCLan please go to http://www.uclan.ac.uk/research/

All outputs in CLoK are protected by Intellectual Property Rights law, including Copyright law. Copyright, IPR and Moral Rights for the works on this site are retained by the individual authors and/or other copyright owners. Terms and conditions for use of this material are defined in the policies page.

\section{CLoK}

Central Lancashire online Knowledge www.clok.uclan.ac.uk

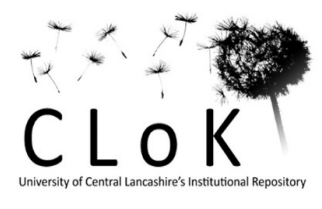




\title{
Mediation in the Law Curriculum
}

\author{
Kartina A. Choong*
}

Paper presented at the Learning in Law Annual Conference, UK Centre for Legal Education (www.ukcle.ac.uk ), University of Warwick, January 2007

\section{Introduction}

Legal education in the United Kingdom has, for a long time, been organized around litigation in the higher courts. ${ }^{1}$ This has led to a curriculum which places an almost exclusive emphasis on the adversarial system of law that has, at its heart, a rightsbased approach to dispute analysis. Since the end of the last century, this disputing model has come under intense criticism for its costliness, inordinate length, complexity and frequent failure to meet the needs of the parties in dispute. This frustration was perhaps nowhere more forcefully voiced than in the Woolf Report. ${ }^{2}$ Policy makers and court officials have, since then, striven to draw attention to the fact that court actions are not always the most appropriate means for resolving disputes and that as far as possible, litigation should be the last, rather than the first resort in such matters. The same parties have actively promoted mediation as a more costeffective and less time-consuming alternative to the adversarial system. ${ }^{3}$

\footnotetext{
* Lecturer in Law, University of Reading, UK.

I am grateful to Ademola Abass, Tabarak Ballal, Francis Botchway, Simon Madden, Carl Stychin and James Torr for their helpful comments.

${ }^{1}$ Report of the Committee on Legal Education (London: HMSO, 1971) p. 9; Stychin, C. F. \& Mulcahy, L., Legal Methods and Systems: Texts and Materials (London: Sweet \& Maxwell, 2007) p. 345.

${ }^{2}$ Lord Woolf, Access to Justice: Final Report to the Lord Chancellor on the Civil Justice System of England and Wales (London: HMSO, 1996); Access to Justice: Interim Report to the Lord Chancellor on the Civil Justice System of England and Wales (London: HMSO, 1995).

${ }^{3}$ See the discussion below.
} 
All these are inevitably having a profound impact on legal practice. The general trend towards more "pre-action" activity ${ }^{4}$ renders it increasingly important for lawyers to be able to serve as "strategic and skilful facilitat[ors] of peace" in addition to their traditional function as "manager[s] of war". ${ }^{5}$ At the same time, it does not appear that the changes have left enough of an imprint on the undergraduate legal curriculum. ${ }^{6}$ This work puts forward the view that the subject should make a stronger presence during the academic stage of legal training.

The paper takes a closer look at what mediation entails and this is followed by a review of the association between mediation and law. It will then address some common concerns that have been raised in connection with mediation, before proceeding to highlight the benefits that could be obtained from the incorporation of mediation into the undergraduate law curriculum. The paper ends by considering whether the change could be accommodated within the existing law degree framework.

\section{Mediation: The Concept}

Mediation has been described as "the process by which the participants, together with the assistance of a neutral person or persons, systematically isolate disputed issues in order to develop options, consider alternatives, and reach a consensual settlement that will accommodate their needs."7 In terms of process and outcome, it offers a fundamentally different way of resolving disputes from the adversarial

\footnotetext{
${ }^{4}$ Ashford, C., 'The $21^{\text {st }}$ century law school: choices, challenges and opportunities ahead' (2006) 3 Web Journal of Current Legal Issues.

${ }^{5}$ MacFarlane, J., 'The new advocacy: implications for legal education and teaching practice' in R. Burridge, K. Hinett, A. Paliwala, \& T. Varnava, Effective Learning and Teaching in Law (London: Kogan Page Ltd., 2002) p. 164.

Ashford, C., op. cit.. Any effort in this direction are mostly carried out in connection to introductory courses in Law when the Woolf Report is referred to within a wider discussion of Alternative Dispute Resolution (ADR).

${ }^{7}$ Folberg, J. \& Taylor, A., Mediation: A Comprehensive Guide to Resolving Conflicts Without Litigation (San Francisco: Jossey-Bass Inc. Publishers, 1984) p. 7.
} 
system. As can be gleaned from the description, mediation is a collaborative process which involves all disputants in the discussion even if they are legally represented. The mediator himself does not have the authority to decide for nor impose the outcome on the disputants. Rather, his role is to encourage the parties to communicate and to assist them to reach a resolution that is acceptable to all sides ${ }^{8}$. In so doing, the focus throughout is on the parties' needs and interests. Since mediation has the ability to bring about solutions that are beyond the powers of the court to provide, ${ }^{9}$ a broader range of solutions other than just monetary compensation are explored. ${ }^{10}$ The decision to participate in the mediation itself should be arrived at voluntarily and parties are free to withdraw from the process at any time. ${ }^{11}$ The ideology of mediation therefore stresses self-determination and democratic decision-making. ${ }^{12}$

It is said that the process is able to lead to mutual satisfaction with outcomes and is less strenuous on the parties. ${ }^{13}$ These make it possible for them to maintain their relationship with one another long after the mediation is over. ${ }^{14}$ It also involves lower transaction costs and time. Here, the private nature of mediation is often deemed as another distinct advantage, and communications between the parties will be treated

\footnotetext{
${ }^{8}$ Noone, M., Mediation (London: Cavendish Publishing Ltd., 1998) pp. 36-37.

${ }^{9}$ Dunnett v. Railtrack plc [2002] 1 WLR 2434 per Brooke LJ at 2437.

${ }^{10}$ In health care disputes, for instance, this can be particularly useful in view of the fact that monetary remedies would not necessarily be what patients are looking for when actions are taken against their doctors. A sincere and heartfelt apology may be all that they want, or perhaps an in-depth explanation of the procedure performed, or an undertaking that policies and procedures would be reviewed so as to ensure that the same thing does not happen to other patients - see L. Mulcahy, et. al., Mediating Medical Negligence Claims: An Option for the Future? (London: University of London Press, 2000) pp. 12-14.

${ }^{11}$ Noone, M., op. cit., p. 7.

12 Vanderkooi, L. \& Pearson, J., 'Mediating divorce disputes: mediator behaviors, styles and roles' (1983) 32 Family Relations 557 at 564; Alfini, J. J., et. al., Mediation Theory and Practice (Newark: Lexis Nexis, 2001) p. 1.

${ }^{13}$ Ury, W. L., Brett, J. M. \& Goldberg, S. B., Getting Disputes Resolved: Designing Systems to Cut the Costs of Conflict (San Francisco: Jossey-Bass Publishers, 1988) p. 15.

${ }^{14}$ Acland, A. F., A Sudden Break of Common Sense: Managing Conflict Through Mediation (London: Hutchinson Business Books Ltd., 1990) p. 22.
} 
as confidential and without prejudice. ${ }^{15}$ The process itself is informal and nonbinding, although a signed mediated agreement is a legally enforceable contract. ${ }^{16}$

Mediation is, as described by one commentator, the adjustable spanner in the dispute-resolution tool-box'. ${ }^{17}$ It has been reported to be effective for a wide range of conflicts including those between: family members; ${ }^{18}$ landlords and tenants; neighbours and members of community; ${ }^{19}$ employers and employees; ${ }^{20}$ colleagues at work; ${ }^{21}$ professionals and clients $;{ }^{22}$ public authorities and individuals; ${ }^{23}$ organisations (and organisations and individuals); businesses; ${ }^{24}$ and states. ${ }^{25}$ This ability to facilitate interpersonal, intergroup and international ${ }^{26}$ conflict resolution has in turn given rise to various models of mediation like family mediation; community mediation; workplace mediation; and commercial mediation. It has also led to the deployment of different methods of mediating (e.g., telephone-based facilitation, face-to-face and online mediation) and numerous techniques (e.g. an opening statement; joint meetings; the use of caucuses; and oral and written agreements). ${ }^{27}$

\footnotetext{
${ }^{15}$ Zamboni, M., 'Confidentiality in mediation' (2003) 6(5) International Arbitration Law Review 175; Noone, M., op. cit., pp. 7-8.

${ }^{16}$ Genn, H., 'Court-based ADR initiatives for non-family civil disputes: the Commercial Court and the Court of Appeal' (2002), available at http: www.hmcourtsservice.gov.uk/docs/adr initiatives.pdf, p. 1.

${ }_{17}^{17}$ Acland, A. F., op. cit., p. 2.

${ }^{18}$ Roberts, M., Mediation in Family Disputes (Aldershot: Wildwood House Limited, 1988); J. Westcott (ed.), Family Mediation: Past, Present and Future (Bristol: Jordan Publishing Ltd., 2004).

${ }^{19}$ Lord Chancellor's Department, Resolving Disputes Without Going to Court, December 1995.

${ }^{20}$ Rehmus, C. M., 'The mediation of industrial conflict: a note on the literature' (1965) 9(1) Journal of Conflict Resolution 118.

${ }^{21}$ Brown, H. \& Marriott, A., ADR Principles and Practice (London: Sweet \& Maxwell, 1999) pp. 131-135.

${ }^{22}$ Mulcahy, L., et. al., op. cit.

${ }^{23} R$ (on the application of Cowl) v. Plymouth City Council [2002] 1 WLR 803.

${ }^{24}$ Turner, D. F. \& Turner, A., Building Contract Claims and Disputes (Essex: Addison Wesley Longman Ltd., 1999) pp. 448-449.

${ }^{25}$ Bercovitch, J., Anagnoson, J. T. \& Wille, D. L., 'Some conceptual issues and empirical trends in the study of successful mediation in international relations' (1991) 28(1) Journal of Peace Research 7; Greig, J. M., 'Recognizing conditions of ripeness for international mediation between enduring rivals' (2001) 45(6) Journal of Conflict Resolution 691.

${ }^{26}$ Wall, J. A., 'Mediation: a current review' (1993) 37(1) Journal of Conflict Resolution 160.

${ }^{27}$ Mackie, K., et. al., The ADR Practice Guide: Commercial Dispute Resolution (West Sussex: Tottel Publishing, 2005) chapters $11 \& 12$.
} 


\section{Mediation and Law}

In many countries, the association between mediation and law took root when mediation was used as a complement to, supplement for or replacement of traditional court adjudication. ${ }^{28}$ These are usually premised on the desire to alleviate the negative effects of high caseloads and to promote efficiency in dispute processing. ${ }^{29}$ In the UK, dispute resolution has been steered in this direction since the end of the $20^{\text {th }}$ century. ${ }^{30}$ In 1993 , for instance, as a result of the discussion leading up to the publication of the Woolf Report, judges in the Commercial Court began to issue ADR orders to disputing parties. These required them to try using the services of a mediator before being allowed to proceed with the litigation and the court would want to be informed of the steps they have taken to do so. ${ }^{31}$ In the same year, a pilot ADR scheme was launched by the Court of Appeal, under which certain appeal cases were mediated by senior lawyer-mediators who provided their services on pro bono basis. $^{32}$ For disputes relating to family matters, the Family Law Act 1996 stated that disputants would not be granted legal aid for representation unless they have first attended a meeting with a mediator to ascertain the suitability of mediation for the resolution of the particular dispute. ${ }^{33}$ They would then receive advice on whether to apply for financial assistance for mediation rather than legal representation. ${ }^{34}$

A pilot mediation scheme was also established at the Central London County Court (CLCC) in $1996 .{ }^{35}$ The scheme's aim was to give parties who were involved in nonfamily civil disputes involving a sum of over $£ 3000$ the opportunity to have their

\footnotetext{
${ }^{28}$ Adler, P., Lovaas, K., \& Milner, N., 'The ideologies of mediation: the movement's own story' (1988) 10(4) Law and Policy 317.

${ }^{29}$ Funken, K., 'Comparative dispute management: court-connected mediation in Japan and Germany', available at http://papers.ssrn.com/abstract=293495, pp. 10 \& 15.

${ }^{30}$ Roberts, S. \& Palmer, M., Dispute Processes: ADR and the Primary Forms of DecisionMaking (Cambridge: Cambridge University Press, 2005) p. 4.

${ }^{31}$ Genn, H., Mediation in Action: Resolving Court Disputes Without Trial (London: Calouste Gulbenkian Foundation, 1999) p. 20.

${ }_{32}$ Ibid.

${ }^{33}$ S.29.

34 Ibid.

${ }^{35}$ Genn, H. (1999), op. cit., p. 27.
} 
disputes mediated by court-appointed mediators at an early stage in litigation. ${ }^{36}$ In the first two years of its operation, around $62 \%$ of the cases settled at the end of the allotted 3-hour session. ${ }^{37}$ A further $18 \%$ settled soon afterwards, and satisfaction was registered by users over issues like costs, informality of the process and fairness of the outcome. ${ }^{38}$ The scheme has since become a permanent part of the court. April 1999 then witnessed the coming into force of the Civil Procedure Rules 1998 which were introduced in response to the Woolf Report. Rules 1.4 and 44.5 state that courts must encourage parties to litigation to use mediation or another ADR procedure as part of the effective management of the case, and a disputing party who fails to cooperate could be penalised through a costs order. ${ }^{39}$

The momentum gathered pace when the Department of Constitutional Affairs (DCA), in conjunction with the Civil Mediation Council (CMC), set up the National Mediation Helpline in November 2004. The service aims to provide civil court users with information about the basic principles of mediation and deal with enquiries relating to mediation. ${ }^{40}$ It could also put them in contact with an accredited mediation provider who could in turn assign a mediator who would be able to help the parties deal with their dispute. Meanwhile, the success ${ }^{41}$ experienced by the CLCC has inspired a number of courts to implement their own mediation schemes. ${ }^{42}$ The Court Mediation

\footnotetext{
${ }^{36}$ Genn, H., 'The Central London County Court Pilot Mediation Scheme Evaluation Report' (2001) 67(1) Arbitration 109.

${ }_{37}^{37}$ Genn, H. (1999), op. cit., p. 35.

${ }^{38}$ Ibid.

${ }^{39}$ See also Halsey v. Milton Keynes General NHS Trust [2004] 1 WLR 3002; Dunnett v. Railtrack plc. [2002] 1 WLR 2434 and Hurst v. Leeming [2003] EWHC 499 (Ch).

${ }^{40}$ National Mediation Helpline, see http://www.nationalmediationhelpline.com.

${ }^{41}$ Success in this context is usually measured in terms of settlement rates.

42 Many of these were equally successful. For instance, the Small Claims Mediation Service pilot scheme at Manchester County Court recorded a high settlement rate of $86 \%$ and an estimated saving of a total of 172 hours of judicial time in the 12-month pilot which took place from June 2005 through May 2006. During the same period, the Small Claims Mediation Service at Exeter County Court showed a $65 \%$ settlement rate and an estimated saving of 121 hours of judicial time; and although by comparison the Small Claims Support Service Pilot at Reading County Court showed a smaller settlement rate of $24 \%$, it was estimated that these helped save 74 hours of judicial time - see Doyle, M., Evaluation of the Small Claims Mediation Service at Manchester County Court (Department of Constitutional Affairs, 2006);
} 
Service Toolkit was, for that reason, launched by Her Majesty's Court Services (HMCS) in April 2006 to provide those wishing to set up their own scheme with practical guidance on how to bring a new mediation scheme into operation. ${ }^{43}$ When the Ministry of Justice was launched in 2007, it echoed the view that courts should be the last resort for people involved in civil or family disputes, and confirmed its commitment to promote the use of mediation as an alternative or an adjunct to litigation. ${ }^{44}$

These developments mirror the vigour with which mediation has been endorsed by the government and the courts in the last decade. The ever stronger relationship that has consequently developed between mediation and law signifies that a curriculum that focuses only on the adversarial rights-based approach to dispute resolution is not likely to be able to produce law graduates who are sufficiently informed about changes that are taking place in legal practice.

\section{Common Concerns About Mediation}

Before going further to outline the benefits that could be obtained from introducing mediation into the law degree programme, it is important at this stage to address some of the concerns that have been raised in relation to mediation. One of these is the claim that since mediation is an informal and consensual process, the absence of procedural and substantive rules may well amplify any existing power imbalances

Prince, S. \& Belcher, S., An Evaluation of the Small Claims Dispute Resolution Pilot at Exeter County Court (Department of Constitutional Affairs, 2006); Craigforth, Evaluation of the Small Claims Support Service Pilot at Reading County Court (Department of Constitutional Affairs, 2006).

${ }^{43}$ HMCS, Court Mediation Service Toolkit (April 2006). The HMCS and the DCA were likewise responsible for organizing a National Mediation Week in 2005 and 2006 to raise the profile of mediation as an alternative method of dispute resolution. During this campaign, the public, advice agencies and members of the legal profession are introduced to, among other things, how the process works, its benefits, the types of disputes that could be solved by mediation, and how one could be arranged - see the HMCS' Mediation Week leaflet, located at http://www.hmcourts-service.gov.uk/mediationweek.

${ }^{44}$ See http://www.justice.gov.uk/whatwedo/alternativedisputeresolution.htm. 
between the disputants. ${ }^{45}$ It was pointed out that since an economically disadvantaged party may be less able to assemble the information that would allow him to predict the outcome of the case should it proceed to litigation, this could put him in a disadvantageous position in the bargaining process. Further, even if he is aware that he would be able to obtain higher damages if the case went to trial, he could be manipulated and induced to settle for a sum that is far smaller than his claim is actually worth if he is in immediate need of the money. He could likewise be coerced to settle if he does not have the means to finance the litigation. In all these, the stronger party would be in a good position to take advantage of a weaker party, hence leading to biases in the outcome. ${ }^{46}$

The private and informal nature also does not, it has been asserted, adequately protect disputants from mediators' biases. ${ }^{47}$ Although mediators are assumed and expected to be impartial, there is ample room for the possibility of the mediator's displaying partiality particularly as the process involves many meetings that are carried out with the parties separately, and much of what was discussed are not disclosed to the other side nor formally recorded. These biases can take many forms - from prejudice in favour or against a disputant on grounds like race, gender, sexual orientation, disability, religion or class; to the mediator's own values and disposition on certain outcomes or personalities. ${ }^{48}$ They can also manifest themselves in a number of ways including the framing and selection of issues, the ranking of settlement issues, or the imposition of a hidden agenda on the parties; all of which, it was argued, could lead to unjust outcomes. ${ }^{49}$

\footnotetext{
${ }^{45}$ Bush, R. \& Folger, J., The Promise of Mediation (San Francisco: Jossey-Bass, 1994) p. 22.

${ }^{46}$ Fiss, O., 'Against settlement' (1984) 93 Yale Law Journal 1073 at 1076.

${ }^{47}$ Bush, R. \& Folger, J., op. cit., p. 23 ; Grillo, T., 'The mediation alternative: process dangers for women' (1991) 100 Yale law Journal 1545 at 1587.

${ }^{48}$ Grillo, T., ibid.

${ }^{49}$ Bush, R. \& Folger, J., op. cit., p. 23.
} 
One other concern is directed at court-connected mediation itself. The idea that mediation could be ordered or proposed by the courts is said to run counter to the central tenets of mediation, a process which prides itself on its voluntary and democratic nature..$^{50}$ Even if the law may not be mandating an agreement, by requiring disputants to try mediation before their cases are heard, it was feared that court-connected mediation would render illusory the notion that the parties are making their own decisions both as regards the choice of entering into the process and their participation throughout. ${ }^{51}$

In the mean time, a claim was made that settlement itself undermines the remedial dimensions and the social function of litigation. ${ }^{52}$ According to this viewpoint, since litigation uses public resources and deploys the services of public officials whose duty it is to clarify and give force to the values enshrined in authoritative texts like statutes, the opportunity for an interpretation is missed out on when parties settle..$^{53}$ The loss to society as a whole is stark particularly where the situation under consideration is one that could benefit from judicial pronouncement. ${ }^{54}$ Settlement would, thereby be a poor substitute for judgement as it "leav[es] justice undone" ${ }^{55}$

Returning to the concerns raised in relation to the process' informal and private nature, there is indeed validity in the contention that inequality of bargaining power can have an adverse effect on the outcome. ${ }^{56}$ The argument, however, seemed to focus largely on economic power and overlooks the fact that the difficulties could in

\footnotetext{
${ }^{50}$ Grillo, T., op. cit., p. 1581.

51 Ibid.

${ }_{53}^{52}$ Fiss, O., op. cit., p. 1085.

${ }^{53}$ Ibid.

${ }^{54}$ For example, those involving allegations of racial discrimination, work-related injuries and police brutality - ibid., pp. 1076 \& 1089.

${ }^{55}$ Ibid., p. 1085.

${ }^{56}$ Kochan, T. A. \& Jick, T., 'The public sector mediation process: a theory and empirical examination' (1978) 22(2) Journal of Conflict Resolution 209 at 229-231.
} 
effect move beyond this form of power disparity to include social and political ones. ${ }^{57}$ Neither do these necessarily favour the powerful party at the expense of the weaker party. A public figure, for example, may feel inclined to reach a settlement on terms more favourable to the other party if this is deemed as being more acceptable than to have the case contested in public. Likewise, a business worried that the public's faith in its integrity would be affected should its dispute with its employees enter the public arena could feel compelled to settle as soon as possible on terms it may not be entirely satisfied with. On this and the matter of mediator bias, there is a larger issue at stake. Because mediators need to work in close physical and emotional proximities with disputants, it is necessary for them to be sensitive to the problems which power disparities may bring up and how these could be minimized. ${ }^{58}$ It is also vital that they should have sufficient awareness of their own unacknowledged perspectives and unrecognized partiality, as these could indeed have an impact on the quality of the mediation and its outcome. ${ }^{59}$ Similarly with the abilities to explore the covert reasons for a dispute ${ }^{60}$ and to detect worldview incompatibilities, ${ }^{61}$ as well as an appreciation of pnenomena like projection, transference and countertransference. $^{62}$ As these may take extensive training and time to develop, the concerns raised about power disparities and mediator bias point to the need for closer monitoring of mediation training ${ }^{63}$ and the regulation of its practice. ${ }^{64}$

\footnotetext{
${ }^{57}$ Bercovitch, J., Anagnoson, J. T. \& Wille, D. L., op. cit., p. 10.

${ }^{58}$ Ott, M. C., 'Mediation as a method of conflict resolution: two cases' (1972) 26 International Organization 595.

59 Grillo, T., op. cit., p. 1589; Smith J. D. D., 'Mediator impartiality: banishing the chimera' (1994) 31(4) Journal of Peace Research 445.

${ }^{60}$ E.g. pride, jealousy, anger, hurt, envy, kudos, arrogance, greed, vanity, the protection of identity and self-esteem - see F. Strasser \& P. Randolph, Mediation: A Psychological Insight Into Conflict Resolution (London: Continuum, 2004) p. 27.

${ }^{61}$ Dryzek, J. S. \& Hunter, S., 'Environmental mediation for international problems' (1987) 31 International Studies Quarterly 87 at 100.

${ }^{62}$ Grillo, T., op. cit., p. 1590.

${ }^{63}$ Many ADR providers (e.g. The Institute of Arbitrators; Centre for Effective Dispute Resolution; ADRGroup) are currently offering training programmes that could lead to accreditation as Mediators. The training, however, often lasts no longer than a few days and focus predominantly on techniques.

${ }^{64}$ It is still possible for anyone to practise as a Mediator in the UK even without the benefit of any training.
} 
On the anxieties expressed concerning court-annexed mediation, there is certainly force in the argument that the presence of any coercive element could remove much of what makes mediation valuable and attractive in the first place. ${ }^{65}$ Its proponents have sought to justify the coercive stance by arguing that it had been necessitated by the fact that not many people are aware of the benefits of mediation. They therefore do not utilize it enough voluntarily and because of this, they should be coerced into using it and realize its benefits for themselves. ${ }^{66}$ Although court-connected schemes in the UK have yet to make it mandatory for parties to use mediation, ${ }^{67}$ the existence of measures like costs orders and for legal aid application in certain circumstances to be accompanied by the need to firstly consider this method of dispute resolution, are on their own already impacting on the philosophy and practice of mediation. Policymakers would thereby need to ensure that in their enthusiasm to divert more cases from courts, it is not only mediation's promise to save money and judicial time that are given foremost consideration. Mediation's other ideals like party empowerment, voluntariness, and creative outcomes should also be taken seriously. ${ }^{68}$ It is thus hoped that as more people, particularly lawyers, become acquainted with the concept and process, just as the paternalistic outlook becomes less justifiable, so would the grip on the coercive elements be loosened.

In relation to the claim that settlement does not deliver justice because the mechanisms of the law were not executed, it is necessary to note that this argument appears to rest on the assumption that there is a fixed notion of justice. It discounts

\footnotetext{
${ }^{65}$ Grillo, T., op. cit., p. 1608.

${ }^{66}$ Sander, F., et. al., 'Judicial (mis)use of ADR? A debate' (1999) U. Tol. L. Rev. 885 at 886, cited in T. K. Kuhner, 'Court-connected mediation compared: the cases of Argentina and the United States' (2005) http://ssrn.com/abstract=888809, p. 15.

${ }^{67}$ Cf. USA, Argentina, Australia, New Zealand, Norway - see T. K. Kuhner, ibid.; National Audit Office, Legal Services Commission: Legal Aid and Mediation for People Involved in Family Breakdown (London: National Audit Office, 2007).

${ }^{68}$ Kuhner, T. K., ibid., p. 31.
} 
other perspectives on justice ${ }^{69}$ and makes no room for the possibility that just as settlement itself may not necessarily create justice, the same could be said about cases that proceed to court. $^{70}$ For reasons such as poor, unspecialised or idiosyncratic judging to differences in litigants' ability to afford skillful legal representation, litigation does not always lead to a fair result. ${ }^{71}$ Indeed as expressed by Lord Devlin, "we delude ourselves if we think that [litigation] always produces the right judgement." ${ }^{\prime 2}$ That decisions are on occasion overturned by a higher court bear further testimony to the idea that mistakes or incorrect decisions are sometimes made. An appellate confirmation, in the mean time, is no guarantee of correctness. ${ }^{73}$ It is nevertheless true that litigation serves the public as a whole and not only the immediate litigants, and that settlement deprives society of precedence. ${ }^{74}$ However, when parties are in dispute, they are normally more concerned about their own individual grievances rather than about the value of their conflict to society. Justice, to them, may be that which is mutually and satisfactorily agreed with the other disputing party after having had the opportunity to have their voices heard and their needs addressed. ${ }^{75}$ This, rather than a judgement that is declared through the application of the same-rules-for-all which takes no account of the fact that different people have different access to the resources of wealth, education and power. ${ }^{76}$

\footnotetext{
${ }^{69}$ See generally J. Rawls, A Theory of Justice (Massachusetts: Harvard University Press, 1971).

${ }^{70}$ Gifford, T., Where's the Justice?: A Manifesto for Law Reform (Middlesex: Penguin Books, 1986).

${ }^{71}$ Bevan, A. H., Alternative Dispute Resolution: A Lawyer's Guide to Mediation and Other Forms of Dispute Resolution (London: Sweet \& Maxwell, 1992) p. 1.

${ }_{72}$ Quoted in Access to Justice: Interim Report to the Lord Chancellor on the Civil Justice System of England and Wales (London: HMSO, 1995) Chapter 4.

${ }_{73}$ Jolowicz, J. A., 'Adversarial and inquisitorial models of civil procedure' (2003) 52 International and Comparative Law Quarterly 281 at 288.

${ }_{74}^{74}$ Ibid., p. 285.

${ }^{75}$ Conlon, D. E., 'Mediation and the fourfold model of justice' in M. S. Herrman (ed.), The Blackwell Handbook of Mediation: Bridging Theory, Research, and Practice (Oxford: Blackwell Publishing, 2006) p. 247.

${ }^{76}$ Hunt, A., 'Critique and law: legal education and practice' in I. Grigg-Spall \& P. Ireland (eds.), The Critical Lawyers' Handbook (London: Pluto Press, 1992) p. 71.
} 
Obviously it does not follow from this that settlement is the preferred route for all situations. Mediation, as some have pointed out, may not be appropriate for specific cases that fall within the following areas: abuse of power; public law; issues involving human rights; where a legal precedent is needed to clarify the law or inform policy; where a public statement is called for on the importance of an industry practice; and where settlement is deemed as not being in the public interest. ${ }^{77}$ Judicial pronouncement could indeed be very important in those and some other situations. As proper grounding in the two models could give lawyers a better idea of when a particular case is more amenable to mediation or litigation, the next part of the paper takes a closer look at the issues surrounding the assimilation of the consensual, interest-based approach to dispute resolution into the LLB programme.

\section{Introducing Mediation into the Law Curriculum}

In discussing the incorporation of mediation into the undergraduate law curriculum, it is firstly worthwhile to observe that experience elsewhere ${ }^{78}$ appears to suggest that there are at least two viable ways by which mediation could be introduced into the curriculum. One is by offering the subject as a stand-alone module. The main advantage of this method is that it enables an in-depth study of a range of issues including the theoretical underpinnings of the different models of mediation; the structure of a mediation and how it works; the enforceability of the agreements reached in mediation and issues of confidentiality; how mediation fits into the legal process; and the skills required. ${ }^{79}$ To work, this would probably have to be introduced either as a second or third year elective, so that students would have had some exposure by then to the kind of legal disputes that can arise. The other viable method

\footnotetext{
${ }_{78}^{77}$ Court Mediation Service Toolkit, op. cit., p. 10; K. Mackie, et. al., op. cit., p. 53.

${ }^{78}$ i.e. juridictions where mediation is already part of the law curriculum e.g. USA, Australia and New Zealand.

${ }^{79}$ Carr-Gregg, S., 'Alternative dispute resolution in practical legal training - too little, too late?' (1997) 10(1) Journal of Professional Legal Education 23 at 37; Maughan, C. \& Webb, J., Lawyering Skills and the Legal Process (Cambridge: Cambridge University Press, 2005) p. 345.
} 
would be to integrate it throughout the curriculum ${ }^{80}$ by drip-feeding it into subjects where mediation has proved, or is most likely, to be useful. This may include areas like Family Law, Medical Law, Contract and the Sale of Goods, Torts, Housing Law, Employment Law, Information Technology Law, Intellectual Property Law and Environmental Law. The clear advantage of this method lies in the fact that students are able to gain useful insight into how mediation principles could be applied to the resolution of disputes in specific contexts. It would, in addition, allow the knowledge of mediation principles to be disseminated to a wider number of students. It has also been demonstrated that the subject is best delivered through a combination of teaching approaches. The traditional lectures could be enhanced through the deployment of video demonstrations of mediation in practice, use of case-studies and simulated exercises/role-play, skill-building exercises, workshops and talks by practitioners, and observations of actual mediation. ${ }^{81}$

Although these are examples that could be emulated, thought and effort would need to be invested in developing a framework that would be compatible with the legal system in the UK as well as the higher education setting here. Several benefits await such an investment - a number of which would be outlined below.

\section{A. The Benefits}

By introducing mediation into the undergraduate law curriculum, students are offered a broader framework which encompasses not only the competitive, adversarial method of conflict resolution, but also a collaborative and cooperative problem solving one. ${ }^{82}$ This presents them with a wider array of dispute resolution possibilities and a continual opportunity to reflect on the relative strengths and weaknesses of

\footnotetext{
${ }^{80}$ Nolan-Haley, J. M. \& Volpe, M. R., 'Teaching mediation as a lawyering role' (1989) 39 Journal of Legal Education 571.

${ }_{81}$ Ibid., p. 575; Carr-Gregg, S., op. cit., p. 34.

${ }^{82}$ Nolan-Haley, J. M. \& Volpe, M. R., ibid., p. 572.
} 
both models. ${ }^{83}$ As this would give them a firmer idea of when a case would be better dealt with by means of litigation or mediation, ${ }^{84}$ it could in time help ensure that more cases that are suitable for mediation are channeled in this direction rather than the courts. The academic stage of legal education is, as has been highlighted, 'the formative stage of a student's development when intellectual interests and attitudes are acquired which will affect and influence the whole of his subsequent thinking. Seeds of knowledge sown in this period have a better chance of germinating than those sown subsequently." ${ }^{85}$ Hence by exposing students to the collaborative problem-solving mode before the adversarial mindset becomes fossilized, this would in future encourage them to practise and think in a way that is responsive to their clients' needs, and where appropriate, to assist the latter solve their problems in a non-litigious way. ${ }^{86}$

Awareness of how mediation works could also reduce the likelihood of them being obstructive when accompanying clients to a mediation session in the future. It is not unknown for lawyers to have treated the mediation setting as a mini courtroom, and view the mediator as a judge and the other party to the dispute as an opponent. The conflict may be framed in legalistic, antagonistic terms; and adversarial strategies are used (e.g. trying to restrain their clients from answering a particular question; persuading them to accept or reject a proposed resolution based on the likely court outcome; or denying responsibility for all aspects of the claim made by the other party). ${ }^{87}$ They have, in this posture, also acted as primary participants, relegating the disputants to a secondary, less participatory role. ${ }^{88}$ All these could be avoided if

\footnotetext{
${ }^{83}$ Ibid., pp. 575 \& 580 .

${ }^{84}$ Carr-Gregg, S., op. cit., p. 26.

${ }^{85}$ Report of the Committee on Legal Education, op. cit., p. 44.

${ }^{86}$ Carr-Gregg, S., op. cit.; Nolan-Haley, J. M. \& Volpe, M. R., op. cit.

${ }^{87}$ Mulcahy, L., 'Can leopards change their spots? An evaluation of the role of lawyers in medical negligence mediation' (2001) 8(3) International Journal of the Legal Profession 203 at 212-217.

${ }^{88}$ Kuhner, T. K., op. cit., p. 26.
} 
lawyers had, in their earlier training, some understanding of how mediation operates and the philosophy underlying the process. They could then play a more constructive role by, among other things, advising their clients about how the process works and encouraging them to fully participate in it; making opening statements for their clients or helping them to prepare one; assisting their clients identify and analyse their and the other disputant's legitimate needs and interests; offering support and advice to their clients; helping to preserve a courteous and cooperative atmosphere; exploring with their clients a tentative settlement range; participating in the generation of ideas and options; acting as a sounding board during private sessions; and helping to draft the written agreement when a settlement is arrived at. ${ }^{89}$

Further, whether or not they accompany their clients, the knowledge would enable lawyers to prepare them for the mediation sessions. Apart from helping with the selection of a mediator, ${ }^{90}$ this preparatory work could, among other things, involve an investigation and appreciation of the client's and the other disputant's position, motivation and imperatives; an exploration of as many concessions as possible which is likely to be of value to the other side; an explanation of what would and could take place in joint and private sessions; a discussion of the issues that could surface and what documents need to be taken with them; and what should be borne in mind when reaching a settlement with the other party. ${ }^{91} \mathrm{~A}$ lawyer who is sufficiently aware of the dynamics of mediation would therefore be in a position to give his client a clearly thought-out platform from which to negotiate. ${ }^{92}$

\footnotetext{
${ }^{89}$ Genn, H. (1999), op. cit., pp. 48-49; Noone, M., op. cit., pp. 34-36; Maughan, C. \& Webb, J, op. cit., p. 347.

${ }^{0}$ Smith, R. (ed.), Shaping the Future: New Directions in Legal Services (London: Legal Action Group, 1995) p. 55.

${ }_{91}$ Mackie, K., et. al., op. cit., p. 189; Genn, H. (1999), op. cit., pp. 46-47.

${ }^{92}$ Mackie, K., ibid., p. 190.
} 
Even for students who choose not to practise law, an understanding of how mediation operates would still be useful and relevant as the knowledge and skills can be applied in many settings. The active learning which the subject engenders is also likely to make a law degree more attractive to many prospective employers ${ }^{93}$ thus enhancing the employability of the beneficiaries of $21^{\text {st }}$ century legal education.

\section{B. The Rationale of University Legal Education}

Despite its avowed benefits, questions remain about the propriety of introducing mediation into the undergraduate law curriculum. This is because, unlike some jurisdictions where a law degree is a prerequisite for legal practice, ${ }^{94}$ the situation is not so in the UK. It remains possible for graduates from other disciplines to seek to qualify as Barristers or Solicitors, just as not all law graduates seek to enter into either branches of the legal profession. ${ }^{95}$

However, in view of the fact that Law is a subject with strong professional connections, there has always been and shall continue to be uncertainties as to whether a university degree course should be designed primarily to provide students with a liberal education ${ }^{96}$ or whether its main emphasis should be on preparing them for a future career in the legal profession. ${ }^{97}$ As a consequence, two main conceptions of the role of the law school constantly vie for dominance. One, as an academic institution devoted to the advancement of learning about law, and the second is as a

\footnotetext{
${ }^{93}$ Knight, P. \& Yorke, M., 'Defining and addressing employability: a fresh approach' (2002) 2 Exchange 15; ESECT, Pedagogy for employability (York: Higher Education Academy, 2006) p. 6.

${ }^{94}$ E.g. USA and New Zealand - see J. H. Langbein, 'Scholarly and professional objectives in legal education: American trends and English comparisons' in P. B. H. Birks, What Are Law Schools For? (Oxford: Oxford University Press, 1996); Gallavin, C. \& Scragg, R., 'The value of an LLB: comparative perspectives between New Zealand and England and Wales' (2006) 4(2) Journal of Commonwealth Law and Legal Education 123.

${ }^{95}$ Bradney, A., 'Raising the drawbridge: defending university law schools' [1995] 1 Web Journal of Current Legal Issues.

${ }^{96}$ Lord Chancellor's Advisory Committee on Legal Education and Conduct, First Report on Legal Education and Training (London: 1996), para. 4.6; Wilson, J. F., A Survey of Legal Education in the United Kingdom (London: Butterworth \& Co. Ltd., 1966) p. 41.

${ }^{97}$ Wilson, J. F., ibid., p. 41.
} 
service institution for the profession. ${ }^{98}$ The two ideals, however, need not be contradictory and most law schools have chosen to combine elements of both conceptions. ${ }^{99}$ Hence in addition to the long-established practice of providing subjects that offer exemption from some or all of the Part I examination of both branches of the legal profession, ${ }^{100}$ more and more law schools are now offering training on skills prized in legal practice like drafting, advocacy, client interviewing, and negotiation. ${ }^{101}$ These are offered either as compulsory or optional modules. ${ }^{102}$ By giving students the opportunity to understand the application of law in its practical context, these skills-based subjects cannot help but to enhance the study of black letter law itself. ${ }^{103}$ Thus like mediation, they could provide students with the groundwork for an effective academic understanding of the law whilst serving as a foundation and preparation for legal practice. ${ }^{104}$

These developments, amidst other changes like the creation of new subjects, ${ }^{105}$ methodologies, ${ }^{106}$ course delivery, ${ }^{107}$ and assessment methods; ${ }^{108}$ to the embracing of information and communication technology in teaching and learning, ${ }^{109}$ have all caused the undergraduate curriculum to expand. University legal education is

\footnotetext{
${ }^{98}$ Twining, W., 'What are law schools for?' (1995) 46(3) Northern Ireland Legal Quarterly 291 at 295.

99 Ibid.

${ }^{100}$ Report of the Committee on Legal Education, op. cit., p. 24; General Council of the Bar \& Law Society, 'A joint statement issued by the Law Society and the General Council of the Bar on the completion of the initial or academic stage of training by obtaining an undergraduate degree' (1995).

${ }_{101}$ Webb, J. \& Maughan, C. (eds.), Teaching Lawyers' Skills (London: Butterworths, 1996) p. xxv.

${ }^{102}$ Harris, P. \& Beinart, S., 'A survey of law schools in the United Kingdom, 2004' (2005) 39(3) The Law Teacher 299 at 308-310.

${ }^{103}$ Boyle, F., Capps, D., Plowden, P. \& Sandford, C., A Practical Guide to Lawyering Skills (London: Cavendish Publishing Ltd., 2005) preface.

${ }^{104}$ Gallavin, C. \& Scragg, R., op. cit., p. 136.

105 E.g. Information Technology Law, Intellectual Property Law and Medical Law.

${ }^{106}$ E.g. feminist and critical legal theory; law-and-economics.

${ }^{107}$ E.g. part-time, distance/open learning, year abroad, twinning programmes.

${ }^{108}$ E.g. group work and assessment, presentation, projects, portfolios.

109 Leighton, P., "This house regrets the increasing privatization of legal education": background briefing document' (2007) 41(1) The Law Teacher 68 at 69; Thomas, P., 'Legal Education: Then and Now' (2006) 40(3) The Law Teacher 239 at 245-252.
} 
therefore not stagnant. ${ }^{110}$ To the extent that mediation can be the mediating chord between the two philosophies of legal education, room could therefore be made for it to be accommodated within the existing law degree framework.

\section{Conclusion}

Concerns over issues like cost, delay and complexity associated with the traditional adjudication system have led courts and policy-makers to encourage disputants to attempt mediation before going to trial. Although all these are having a profound effect on legal practice, their impact on undergraduate legal education is still minimal. As a consequence, the emphasis still is, just as it has for a long time been, on precedents, evidence and a binary win/lose resolution of a financial nature. ${ }^{111}$ Yet how law is taught has a very real and enduring impact upon how those who are on the receiving end of that teaching approach conflict resolution. ${ }^{112}$ With mediation not something which many lawyers are familiar with, and with it not featuring enough in the undergraduate curriculum, it is not currently an option that would come readily to mind when advising clients. ${ }^{113}$ Some lawyers are even known to have dismissed the option or rendered cautious warning to clients who showed an interest in the method. ${ }^{114}$ As a consequence, litigation which is 'a procedure that should be the last resort too often becomes the first resort'. ${ }^{115}$ In order to reverse the trend, it is, as discussed, important for mediation to make a stronger presence in the undergraduate law curriculum. To refrain from so acting would run the risk of leaving the beneficiaries of $21^{\text {st }}$ century legal education ill-equipped to meet the demands of legal practice in the modern era.

\footnotetext{
${ }^{110}$ Harris, P. \& Beinart, S., op. cit.

${ }_{111}$ Mulcahy, L. (2001), op. cit., p. 215.

112 Van Valkenberg, E. W., 'Law teachers, law students and litigation' (1984) 34 Journal of Legal Education 584 at 586, cited in S. Carr-Gregg, op. cit., p. 39.

${ }_{113}$ National Audit Office, op. cit.

${ }_{115}^{114}$ Smith , R., op. cit., p. 56.

${ }^{115}$ Ury, W. L., et. al., op. cit., p. 18.
} 


\section{Bibliography}

Acland, A. F., A Sudden Break of Common Sense: Managing Conflict Through Mediation (London: Hutchinson Business Books Ltd., 1990).

Adler, P., Lovaas, K., \& Milner, N., 'The ideologies of mediation: the movement's own story' (1988) 10(4) Law and Policy 317.

Alfini, J. J., et. al., Mediation Theory and Practice (Newark: Lexis Nexis, 2001).

Ashford, C., 'The $21^{\text {st }}$ century law school: choices, challenges and opportunities ahead' (2006) 3 Web Journal of Current Legal Issues.

Bercovitch, J., Anagnoson, J. T. \& Wille, D. L., 'Some conceptual issues and empirical trends in the study of successful mediation in international relations' (1991) 28(1) Journal of Peace Research 7.

Bevan, A. H., Alternative Dispute Resolution: A Lawyer's Guide to Mediation and Other Forms of Dispute Resolution (London: Sweet \& Maxwell, 1992).

Birks, P. B. H., What Are Law Schools For? (Oxford: Oxford University Press, 1996).

Boyle, F., Capps, D., Plowden, P. \& Sandford, C., A Practical Guide to Lawyering Skills (London: Cavendish Publishing Ltd., 2005).

Bradney, A., 'Raising the drawbridge: defending university law schools' [1995] 1 Web Journal of Current Legal Issues.

Brown, H. \& Marriott, A., ADR Principles and Practice (London: Sweet \& Maxwell, 1999).

Burridge, R., Hinett, K., Paliwala, A. \& Varnava, T., Effective Learning and Teaching in Law (London: Kogan Page Ltd., 2002).

Bush, R. \& Folger, J., The Promise of Mediation (San Francisco: Jossey-Bass, 1994).

Carr-Gregg, S., 'Alternative dispute resolution in practical legal training - too little, too late?' (1997) 10(1) Journal of Professional Legal Education 23.

Craigforth, Evaluation of the Small Claims Support Service Pilot at Reading County Court (Department of Constitutional Affairs, 2006).

Doyle, M., Evaluation of the Small Claims Mediation Service at Manchester County Court (Department of Constitutional Affairs, 2006).

Dryzek, J. S. \& Hunter, S., 'Environmental mediation for international problems' (1987) 31 International Studies Quarterly 87 at 100.

ESECT, Pedagogy for Employability (York: Higher Education Academy, 2006).

Fiss, O., 'Against settlement' (1984) 93 Yale Law Journal 1073. 
Folberg, J. \& Taylor, A., Mediation: A Comprehensive Guide to Resolving Conflicts Without Litigation (San Francisco: Jossey-Bass Inc. Publishers, 1984).

Funken, K., 'Comparative dispute management: court-connected mediation in Japan and Germany', available at http://papers.ssrn.com/abstract=293495.

Gallavin, C. \& Scragg, R., 'The value of an LLB: comparative perspectives between New Zealand and England and Wales' (2006) 4(2) Journal of Commonwealth Law and Legal Education 123

General Council of the Bar \& Law Society, 'A joint statement issued by the Law Society and the General Council of the Bar on the completion of the initial or academic stage of training by obtaining an undergraduate degree' (1995).

Genn, H., 'Court-based ADR initiatives for non-family civil disputes: the Commercial Court and the Court of Appeal' (2002), available at http://www.hmcourtsservice.gov.uk/docs/adr initiatives.pdf.

Genn, H., Mediation in Action: Resolving Court Disputes Without Trial (London: Calouste Gulbenkian Foundation, 1999).

Genn, H., 'The Central London County Court Pilot Mediation Scheme Evaluation Report' (2001) 67(1) Arbitration 109.

Greig, J. M., 'Recognizing conditions of ripeness for international mediation between enduring rivals' (2001) 45(6) Journal of Conflict Resolution 691.

Grigg-Spall, I. \& Ireland, P. (eds.), The Critical Lawyers' Handbook (London: Pluto Press, 1992).

Grillo, T., 'The mediation alternative: process dangers for women' (1991) 100 Yale Law Journal 1545.

Harris, P. \& Beinart, S., 'A survey of law schools in the United Kingdom, 2004' (2005) 39(3) The Law Teacher 299.

Herrman, M. S. (ed.), The Blackwell Handbook of Mediation: Bridging Theory, Research, and Practice (Oxford: Blackwell Publishing, 2006).

HMCS, Court Mediation Service Toolkit (April 2006).

Jolowicz, J. A., 'Adversarial and inquisitorial models of civil procedure' (2003) 52 International and Comparative Law Quarterly 281.

Knight, P. \& Yorke, M., 'Defining and addressing employability: a fresh approach' (2002) 2 Exchange 15.

Kochan, T. A. \& Jick, T., 'The public sector mediation process: a theory and empirical examination' (1978) 22(2) Journal of Conflict Resolution 209.

Kuhner, T. K., 'Court-connected mediation compared: the cases of Argentina and the United States' (2005) http://ssrn.com/abstract=888809.

Leighton, P., "This house regrets the increasing privatization of legal education": background briefing document' (2007) 41(1) The Law Teacher 68. 
Lord Chancellor's Advisory Committee on Legal Education and Conduct, First Report on Legal Education and Training (London: 1996).

Lord Chancellor's Department, Resolving Disputes Without Going to Court (1995).

Mackie, K., et. al., The ADR Practice Guide: Commercial Dispute Resolution (West Sussex: Tottel Publishing, 2005).

Maughan, C. \& Webb, J., Lawyering Skills and the Legal Process (Cambridge: Cambridge University Press, 2005).

Mulcahy, L., 'Can leopards change their spots? An evaluation of the role of lawyers in medical negligence mediation' (2001) 8(3) International Journal of the Legal Profession 203.

Mulcahy, L., et. al., Mediating Medical Negligence Claims: An Option for the Future? (London: University of London Press, 2000).

National Audit Office, Legal Services Commission: Legal Aid and Mediation for People Involved in Family Breakdown (London: National Audit Office, 2007).

National Mediation Helpline, http://www.nationalmediationhelpline.com.

Nolan-Haley, J. M. \& Volpe, M. R., 'Teaching mediation as a lawyering role' (1989) 39 Journal of Legal Education 571.

Noone, M., Mediation (London: Cavendish Publishing Ltd., 1998).

Ott, M. C., 'Mediation as a method of conflict resolution: two cases' (1972) 26 International Organization 595

Prince, S. \& Belcher, S., An Evaluation of the Small Claims Dispute Resolution Pilot at Exeter County Court (Department of Constitutional Affairs, 2006).

Rawls, R., A Theory of Justice (Massachusetts: Harvard University Press, 1971).

Rehmus, C. M., 'The mediation of industrial conflict: a note on the literature' (1965) 9(1) Journal of Conflict Resolution 118.

Report of the Committee on Legal Education (London: HMSO, 1971).

Roberts, M., Mediation in Family Disputes (Aldershot: Wildwood House Limited, 1988).

Roberts, S. \& Palmer, M., Dispute Processes: ADR and the Primary Forms of Decision-Making (Cambridge: Cambridge University Press, 2005).

Smith J. D. D., 'Mediator impartiality: banishing the chimera' (1994) 31(4) Journal of Peace Research 445.

Smith, R. (ed.), Shaping the Future: New Directions in Legal Services (London: Legal Action Group, 1995). 
Strasser, F. \& Randolph, P., Mediation: A Psychological Insight Into Conflict Resolution (London: Continuum, 2004).

Stychin, C. \& Mulcahy, L., Legal Methods and Systems: Texts and Materials (London: Sweet \& Maxwell, 2007).

Thomas, P., 'Legal Education: Then and Now' (2006) 40(3) The Law Teacher 239.

Turner, D. F. \& Turner, A., Building Contract Claims and Disputes (Essex: Addison Wesley Longman Ltd., 1999).

Twining, W., 'What are law schools for?' (1995) 46(3) Northern Ireland Legal Quarterly 291.

Ury, W. L., Brett, J. M. \& Goldberg, S. B., Getting Disputes Resolved: Designing Systems to Cut the Costs of Conflict (San Francisco: Jossey-Bass Publishers, 1988).

Vanderkooi, L. \& Pearson, J., 'Mediating divorce disputes: mediator behaviors, styles and roles' (1983) 32 Family Relations 557.

Webb, J \& Maughan, C. (eds.), Teaching Lawyers' Skills (London: Butterworths, 1996).

Westcott, J. (ed.), Family Mediation: Past, Present and Future (Bristol: Jordan Publishing Ltd., 2004).

Wilson, J. F., A Survey of Legal Education in the United Kingdom (London: Butterworth \& Co. Ltd., 1966).

Woolf, Lord, Access to Justice: Final Report to the Lord Chancellor on the Civil Justice System of England and Wales (London: HMSO, 1996).

Woolf, Lord, Access to Justice: Interim Report to the Lord Chancellor on the Civil Justice System of England and Wales (London: HMSO, 1995).

Zamboni, M., 'Confidentiality in mediation' (2003) 6(5) International Arbitration Law Review 175. 